\title{
Henna-Induced Haemolysis in an Un-diagnosed G6PD Deficient Arabian Baby-Case Report
}

\author{
Alhazmi AA, Hamedhi FI, Alaksham HM, Mubaraki MA, Hattan M, Mady AM, Zakari EIY, Khan LA* \\ Department of Paediatrics, Prince Mohammed Bin Nasser Hospital Jazan, Kingdom of Saudi Arabia \\ *Corresponding author: Khan LA, Department of Paediatrics, Prince Mohammed Bin Nasser Hospital Jazan, Kingdom of Saudi Arabia, E-mail: \\ drliaqatalikhan@yahoo.com
}

Received date: 28 Nov, 2018; Accepted date: 20 Dec, 2018; Published date: 31 Dec, 2018

Copyright: @ 2018 Alhazmi AA, et al. This is an open-access article distributed under the terms of the Creative Commons Attribution License, which permits unrestricted use, distribution and reproduction in any medium, provided the original author and source are credited.

\begin{abstract}
Henna derived from the dried crushed leaves of the henna plant-Lawsonia inermis Linn- used commonly in ceremonial and social events throughout the Asia, Middle East and Africa that contain an active dye ingredient lawsone. Like other ortho-substituted 1,4-naphthaoquinone, lawsone induce oxidative injury to red blood cells, that could be fatal in G6PD deficient infants and rarely in children and adults. We report a previously undiagnosed G6PD deficient Arabian baby with life threatening haemolysis after topical application of henna.
\end{abstract}

Keywords: Henna; Lawsone; Haemolysis; G6PD deficiency

\section{Introduction}

Worldwide Glucose-6-Phosphate Dehydrogenase (G6PD) deficiency is the most prevalent enzymopathy that affects over 400 million individuals [1]. G6PD deficiency, prevalence varies by geographical location. It is higher is some parts of the world and low in others and differs among different ethnic groups like in Sub-Saharan Africans (7.5\%), Middle East (6.0\%) and Asians (4.7\%) are affected more than the Americans (3.4\%), Europeans (3.9\%) and the Pacific Icelanders (2.9\%) [2].

Most people with G6PD deficiency, however, do not exhibit symptoms unless exposed to stressors like, infections, oxidative medicine and or fava beans. The main clinical manifestations of G6PDd are acute haemolytic anaemia, chronic non-spherocytic haemolytic anaemia, neonatal jaundice and favism $[1,3]$.

Henna also called "Mehendi" is a traditional cosmetic agent, used worldwide especially in Asia, Middle East and Africa, not only for cosmetic purposes to stain the hairs, skin and nails in different ceremonial occasions but also used as medicine to treat various bacterial, and fungal infections [4-6]. Lawsone, the active dye component of henna induces oxidative injury to red blood cells that could be fatal in in G6PD deficient individuals.

We report a 4-month old arabian baby girl, previously undiagnosed with G6PD deficiency, who developed life threatening hemolysis after topical application of henna to her body.

\section{Case Report}

A 4-month old female baby brought by her parents to the pediatric emergency department with history of fever, yellowish tinge skin and poor feeding for the last two days. The history is suggestive of henna application to the infant's body three days prior to presentation. Her past medical history was unremarkable while her mother had the same episode on her wedding night after applying henna but left unnoticed (quantitative level of mother G6PD enzyme was $20 \mathrm{mU} / 10^{9} \mathrm{RBCs}$ ).
Physical examination revealed an icteric baby with an axillary temperature of $36.5^{\circ} \mathrm{C}$, pulse $110 / \mathrm{min}$, respiratory rate of $28 / \mathrm{min}$, blood pressure of $119 / 55 \mathrm{mmHg}$ and oxygen saturation of $98 \%$ in room air. Other clinical findings were unremarkable except a short systolic murmur on left sternal border.

Laboratory work-up showed haemoglobin $6.4 \mathrm{~g} / \mathrm{dL}$, hematocrit $22.4 \%$, white blood cell count of $23.50 \times 103 / \mu \mathrm{L}$, red blood cell count $2.45 \times 106 / \mu \mathrm{L}$ and platelet count $343 \times 103 / \mu \mathrm{L}$, MCV $82 \mathrm{fL}$ and RDW $13 \%$.

Peripheral blood smear showed 27.1\% neutrophils, $66.2 \%$ lymphocytes, anisocytosis $(+)$, poikilocytosis $(+)$, spherocytosis (-), Heinz body $(+)$ and reticulocyte count $5.5 \%$. Biochemical analysis yielded total serum bilirubin $13 \mathrm{mg} / \mathrm{dL}$, indirect bilirubin $2.9 \mathrm{mg} / \mathrm{dL}$, blood asparate aminotransferase $131 \mathrm{iu} / \mathrm{L}$, serum urea $12 \mathrm{mg} / \mathrm{dL}$, creatinine $0.36 \mathrm{mg} / \mathrm{dL}$, and other biochemical parameters were within normal limits. Serology tests for HAV, HBV, and HCV were negative. Blood test for malaria, direct coombs test and blood culture was negative. Haemoglobin electrophoresis was within normal range. Urine analysis showed yellow colored urine, specific gravity: 1015, bilirubin (Nil), hemoglobinuria was (Nil). Quantitative G6PD enzyme deficiency of the infant was established and it was low, $104 \mathrm{mU} / 10^{9}$ RBCs (Ref. Range 166-445).

A presumptive diagnosis of henna induced acute haemolysis was made, as other causes of haemolysis like infection and exposure to chemical agents were ruled out, which then came out as G6PD deficient by quantitative analysis.

The patient neither developed renal impairment nor Disseminated Intravascular Coagulation (DIC) and had uneventful recovery after blood transfusion and supportive treatment including adequate hydration and the patient symptoms and laboratory data was recovered. The infant progress was uneventful and discharged on 7th day of admission, with follow-up a week later in good health while the parents were counselled regarding the condition with absolute avoidance of henna and given a list of drugs and food to be avoided. 
Citation: $\quad$ Alhazmi AA, Hamedhi FI, Alaksham HM, Mubaraki MA, Hattan M, et al. (2018) Henna-Induced Haemolysis in an Un-diagnosed G6PD

Page 2 of 2

\section{Discussion}

Henna obtained from the powdered leaves of a shrub that are used not only in religio-cultural events, widely in Asia, Middle East and Africa but also for therapeutic purposes to treat various skin infections. Lawsone that constitute about $1 \%$ of the powdered form of henna leaves is a potent oxidant of G6PD deficient red cells like 1,4 naphthoquinone-a naphthalene metabolite $[7,8]$.

Despite the potential risk of henna induced haemolysis, there are few reported cases of life threatening hemolysis in G6PD-deficient patients due to topical application of henna. The clinical symptoms severity depends on the degree of enzyme deficiency although other factors such as oxidative agent dose, exposure time, patient age, haemoglobin level and concurrent infection do contribute [1].

In the study of Kandel et al. [9] 15 G6PD deficient new borns were reported that were admitted with haemolysis after 24-72 hours of topical henna application. Raupp et al. [10] reported 4 cases of acute hemolysis in G6PD deficient children post-henna application.

In another study Syeyedzadeh et al. [11] reported a 42-days old G6PD-deficient infant who developed acute hemolysis after topical application of henna to treat his napkin dermatitis. Kheri A et al. [12] reported life-threatening haemolysis in a 6-year old boy with undiagnosed G6PD deficiency after topical application of henna, while Soker et al. [7] reported an eleven years old G6PD deficient boy, with henna induced haemolysis to treat his psoriatic skin lesions.

In a recent systemic review, Lee et al. [13] reported 20 cases of hemolysis in G6PD deficient patients due to henna application. Taken together, the available data indicates that henna could increase the risk of hemolysis in G6PD deficient individuals. Our case is the first reported case of henna induced severe haemolysis in a previously undiagnosed G6PD deficient patient, in our paediatric unit of tertiary care hospital despite the high prevalence of G6PD deficiency and popularity of henna in the Arab culture.

The report of this case highlights the risk of life threatening risk of henna to cause acute haemolysis in G6PD deficient patients in specific and undiagnosed cases in general. Thus, henna application should be discouraged generally in unscreened infants and specifically individuals of any age group with a family history or known cases of G6PD deficiency.

\section{Consent}

Written informed consent was obtained from the patient's guardian for publication of this case.

\section{Conflict of interest}

The authors declare no conflict of interest.

\section{References}

1. Cappellini MD, Fiorelli G (2008) Glucose-6-phosphate dehydrogenase deficiency. Lancet 371: 64-74.

2. Nkhoma ET, Poole C, Vannappagari V, Hall SA, Beutler E (2009) The global prevalence of glucose-6-phosphate dehydrogenase deficiency: A systemic review and meta-analysis. Blood Cells Mol Dis 42: 267-278.

3. Luzzatto L (2006) Glucose 6-phosphate dehydrogenase deficiency: From genotype to phenotype. Haematologica 91: 1303-1306.

4. Kathem K. Al-Rubiay, Nawres N Jaber, Al-Mhaawe BH, Laith K. Alrubaiy (2008) Antimicrobial efficacy of henna extracts. Oman Med J 23: 253-256.

5. Kelmanson JE, Jäger AK, van Staden J (2000) Zulu medicinal plants with antibacterial activity. J Ethnopharmacol 69: 241-246.

6. Singh A, Singh DK (2001) Molluscicidal activity of Lawsonia inermis and its binary and tertiary combinations with other plant derived molluscicides. Indian J Exp Biol 39: 263-268.

7. Soker M, Devecioglu C, Haspolat K, Dikicl B, Dogru O (2000) Henna induced acute hemolysis in a G6PD-deficient patient: A case report. Int Pediatr 15: 114-116.

8. McMillan DC, Sarvate SD, Oatis JE Jollow DJ (2004) Role of oxidant stress in lawsone-induced hemolytic anemia. Toxicol Sci 82: 647-655.

9. Kandil HH, Al-Ghanem MM, Sarwat MA, Al-Thallab FS (1996) Henna (Lawsonia inermis Linn.) inducing haemolysis among G6PD-deficient newborns. A new clinical observation. Ann Trop Paediatr 16: 287-291.

10. Raupp P, Hassan JA, Varughese M, Kristiansson B (2001) Henna causes life threatening haemolysis in glucose-6-phosphate dehydrogenase deficiency. Arch Dis Child 85: 411-412.

11. Syeyedzadeh A, Hemmati M, Gheiny S (2007) Henna-induced severe haemolysis: In glucose 6-phosphate dehydrogenase deficiency. Pak J Med Sci 23: 119-121.

12. Kheir A, Gabar I, Gafer S, Ahmed W (2017) Life-threatening haemolysis induced by henna in a Sudanese child with glucose- 6 phosphate dehydrogenase deficiency. East Mediterr Health J 23: 28-30.

13. Lee SWH, Lai NM, Chaiyakunapruk N, Chong DWK (2017) Adverse effects of herbal or dietary supplements in G6PD deficient: a systemic review. Br J Clin Pharmacol 83: 172-179. 